\title{
Differential Susceptibility of Human CNS-Derived Cell Populations to TNF-Dependent and Independent Immune-Mediated Injury
}

\author{
Sameer D'Souza,' Karen Alinauskas, ${ }^{1}$ Ellie McCrea,' Cindi Goodyer, ${ }^{2}$ and Jack P. Antel ${ }^{1}$ \\ 'Neuroimmunology Unit, Department of Neurology and Neurosurgery, and ${ }^{2}$ Department of Pediatrics, McGill \\ University, Montreal, Quebec H3A 2B4, Canada
}

\begin{abstract}
We examined whether oligodendrocytes, neurons, and astroglia derived from the human central nervous system differ in susceptibility to injury mediated by tumor necrosis factor (TNF)- $\alpha$ and by activated $C D 4^{+} T$ cells acting via a TNF-independent mechanism. Injury was assessed either as cell membrane-directed (lysis), measured by ${ }^{51}$ chromium (Cr) or lactate dehydrogenase (LDH) release, or nucleus-directed (apoptosis), measured by morphologic features based on propidium iodide (PI) staining and by DNA fragmentation measured by a terminal transferase (TdT)mediated dUTP biotin nick end labeling technique (TUNEL). TNF did not induce ${ }^{51} \mathrm{Cr}$ or $\mathrm{LDH}$ release in any cell targets, but did induce nuclear (66 $\pm 2 \%$ of cells) and DNA (68 \pm $2 \%$ of cells) fragmentation selectively in the oligodendrocytes over $96 \mathrm{hr}$. At this time, there was no significant loss of oligodendrocyte cell number. Nuclear injury could be induced in neurons by serum deprivation and in malignant astrocytes by the combination of TNF and low serum. CD4+ $T$ cells activated with phytohemagglutin (pha) or anti-CD3 plus interleukin-2 induced significant ${ }^{51} \mathrm{Cr}$ and $\mathrm{LDH}$ release in all target cells tested; only pha-activated CD4+ T-cell cocultures showed reduced target cell numbers. Significant nuclear fragmentation was observed only for glioma cells ( $22 \pm 1 \%$ of cells). Differences in susceptibility to different immune effector mechanisms and in the nature of the injury response to the same effector mediator among human CNS-derived neural cells will need to be considered in design of therapeutic strategies aimed at protecting or limiting target cell injury consequent to disease or trauma.
\end{abstract}

[Key words: oligodendrocytes, cortical neurons, tumor necrosis factor $\alpha(T N F \alpha), C D 4^{+} T$ cells, cytotoxicity, immune injury of CNS]

Cell-mediated immune (CMI) responses are implicated as the primary mediators of tissue injury which occur in an array of inflammatory diseases of the CNS. Such responses can be mediated either by cell-cell contact-dependent or soluble factordependent mechanisms. In multiple sclerosis, myelin and its cell of origin, the oligodendrocyte (OL), are considered the major targets of this response (Bruck et al., 1994). Pathologic and neuroimaging studies indicate that axonal injury also occurs, partic-

$\overline{\text { Received May 8, } 1995 \text {; revised June 21 }}$ 1995; accepted July 5, 1995.

This work was supported by grants from the Medical Research Council of Canada (I.A.) and a Jeanne-Timmins FeJlowship (S.D.S.).

Correspondence should be addressed to Dr. Jack P. Antel, Neuroimmunology Unit, Montreal Neurological Institute, 3801 University Street, Montreal, Quebec H3A 2B4. Canada.

Copyright (C) 1995 Society for Neuroscience $0270-6474 / 95 / 157293-08 \$ 05.00 / 0$ ularly during the progressive phase of the disease (Arnold et al., 1994). In some viral diseases, including HIV encephalopathy, immune effectors contribute to the target cell injury (Wilt et al., 1995). Immune system products are also implicated as secondary contributors to the cellular injury in neurodegenerative disorders such as Alzheimer's disease (McGeer et al., 1989).

A specific issue raised with regard to immune mediators of tissue injury relates to whether different populations of CNS cells are sclectively vulnerable to particular effectors. A corollary would be whether the mechanism of target cell injury to a common effector differs among neural cell populations. Cell injury has usually been considered in terms of primary cell membrane injury (lysis) or nuclear injury (apoptosis).

In the present study, we address these issues using dissociated in vitro cultures of human adult CNS-derived OLs, fetal CNSderived neurons and astrocytes, and human glioma cell lines as target cells. As effector mediators, we used tumor necrosis factor (TNF) $\alpha$ and in vitro-activated CD4 ${ }^{+} \mathrm{T}$ cells. The former, under pathologic conditions in the CNS, may be derived both from infiltrating mononuclear cells and glial cells, both microglia and astrocytes (Robbins et al., 1987; Lee et al., 1993; Williams et al., 1994). TNF $\alpha$ has been shown to induce DNA fragmentation of primary rodent, bovine, and human OLs after 72-96 hr of in vitro exposure (Selmaj et al., 1991) and of the OL precursor cell line CG4, induced to mature in vitro (Louis et al., 1993). The related molecule TNF $\beta$ is at least as toxic to OLs (Selmaj et al., 1991). Gelbard et al. (1993) reported that TNF $\alpha$ was toxic to cultured primary human fetal cortical neurons, as assessed morphologically.

We have previously shown that mitogen- or antigen-activated $\mathrm{CD}^{+} \mathrm{T}$ cells, the $\mathrm{T}$-cell subset used to transfer autoimmune encephalitis in animals, can induce OL cell membrane injury, measured using ${ }^{51} \mathrm{Cr}$ or $\mathrm{LDH}$ release, within $18 \mathrm{hr}$ of effector: target coculture (Antel et al., 1994). The effect is TNF-independent and non-MHC-restricted (Antel et al., 1994). At this time point, there is no evidence of nuclear injury, as measured by a DNA fragmentation assay (McLaurin et al., 1995). In the present study, we have assessed target cell responses to the $\mathrm{T}$-cell effectors in terms of cell membrane and nuclear-directed injury over short (18 hr) and longer term (96 hr) culture. A non-MHCrestricted $\mathrm{CD}^{+}{ }^{+} \mathrm{T}$-cell effector response should be of particular interest in context of CNS cell injury, in that neither neurons or OLs to express MHC class II molccules, the restricting element for antigen-specific CD4 ${ }^{+} \mathrm{T}$ cells.

\section{Materials and Methods}

Preparation of effectors

Recombinant human TNF $\alpha$ used in these studies was obtained from Intermedico Diagnostics (Markham, Ontatario). Preliminary studies es- 
tablished 1000 units $/ \mathrm{ml}$ as a standard dose to perform the comparative studies described in this report (D'Souza et al., unpublished observations).

CD4 ${ }^{+} \mathrm{T}$ cells were prepared from peripheral blood samples obtained from healthy volunteers using an initial Ficoll-hypaque (Pharmacia, Baie D'Urfe, Quebec) gradient centrifugation step (30 min at $500 \times g$ ) to obtain mononuclear cells (MNCs). T cells were isolated by a rosetting technique in which MNCs were incubated for 1 hr at $4^{\circ} \mathrm{C}$ with $\mathrm{S}-(2$ aminoethyl) isothiouroniumbromide hydrobromide (AET) (Aldrich, Milwaukee,WI) treated sheep red blood cells and then centrifuged for $30 \mathrm{~min}$ on a Ficoll-hypaque gradient (Antel et al., 1994). The rosetted cells ( $T$ lymphocytes) were collected from the pellet and the sheep red blood cells were lysed by use of Gey's solution, a hypotonic lysis buffer, for $4 \mathrm{~min}$ at $4^{\circ} \mathrm{C}$. The cells were then centrifuged for $30 \mathrm{~min}$ on a $43.5 \%$ Percoll (Pharmacia) gradient to remove large granular lymphocytes and incubated for $1 \mathrm{hr}$ at $37^{\circ} \mathrm{C}$ with anti-CD8 monoclonal antibody (from ATCC hybridoma cell line CRL 8014) and complement (baby rabbit serum, Cedar Lane, Hamilton, Ontario). Following lysis, the remaining cells (CD4 ${ }^{+} \mathrm{T}$ cells) were collected, washed $3 \times$ in phosphate-buffered saline (PBS), and suspended at $1 \times 10^{6}$ cells per milliliter in culture mediun comprised of RPMI (GIBCO, Burlington, Ontario) supplemented with $5 \%$ human serum (Pel Freeze, Brown Deer, WI), $2.5 \mu \mathrm{g}$ per $\mathrm{ml}$ penicillin and $2.5 \mu \mathrm{g}$ per $\mathrm{ml}$ streptomycin. Cells were placed in $25 \mathrm{~cm}^{2}$ flasks (Falcon, Fisher Scientific, Montreal, Quebec) together with irradiated (2500 rads) autologous nonrosetting $\left(\mathrm{E}^{-}\right)$cells $(2: 1$ ratio) as a source of feeder cells. Cells were activated in vitro for $72 \mathrm{hr}$ with either soluble anti-CD3 antibody (10 $\mu \mathrm{g}$ per ml; ATCC CRL 8001), anti-CD3 plus recombinant human IL-2 $(20 \mathrm{U} / \mathrm{ml}$; gift of Immunex, Seattle, WA), or with phytohemagglutinin (pha) ( $1 \mu \mathrm{g} / \mathrm{ml}$; Wellmark Diagnostics, Guelph, Ontario). Cells were then harvested and centrifuged on a Ficoll-hypaque gradient to remove dead cells. Extent of T-cell activation was assessed by determining ${ }^{3} \mathrm{H}$-thymidine uptake over $5 \mathrm{hr}$ by an aliquot of these cells. Purity of the $\mathrm{CD} 4^{+} \mathrm{T}$ cells was determined by FACScan analysis. The enriched $\mathrm{CD} 4^{+} \mathrm{T}$ cells were washed twice and resuspended in RPMI plus $10 \%$ fetal calf serum (FCS). In some experiments, anti-CD3-stimulated cells were coated with pha immediately prior to their use as effector cells.

\section{Preparation of targets}

Adult CNS-derived cells. OLs were derived from temporal lobe tissue specimens resected from young adults undergoing surgical resection for the treatment of intractable epilepsy. The method of cell isolation, previously described in detail (Yong and Antel, 1992) utilized an initial trypsinization step, followed by Percoll gradient centrifugation. Dissociated cells were cultured in minimum essential medium (MEM) supplemented with $5 \%$ fetal bovine serum (FBS), and $0.1 \%$ glucose. Subsequent separation of glial cell subtypes is based on their differential adhesion to uncoated Falcon tissue culture flasks (Fisher, Montreal, Canada) or petri dishes. Enriched populations of OLs were harvested from the mixed glial preparation in the form of the nonadherent cell fraction after 24 hr and replated on coated petri dishes. After a further $24 \mathrm{hr}$, the nonadherent cells were again collected and placed either into 96 well microtiter wells $\left(5 \times 10^{4}\right.$ cells per well) or onto poly-L-lysinecoated Aclar coverslips $\left(5 \times 10^{4}\right.$ cells per coverslip) which could be placed in 24 well microtiter wells. Cells were allowed to extend processes, being optimal for functional assays within $2-4$ weeks from time of initial isolation.

Fetal CNS-derived cells. Neurons and astrocytes were derived from human fetal CNS tissue (cerebral hemispheres) obtained at 12-16 week gestation, using Medical Research Council of Canada approved guidelines. The cultures were prepared by dissociation of the fetal CNS tissue with $0.05 \%$ trypsin and $50 \mu \mathrm{g} / \mathrm{ml}$ DNase, passing the tissue through a $132 \mu \mathrm{m}$ nylon mesh screen, and then through a $70 \mu \mathrm{m}$ screen. After washing with PBS, the cells were suspended in culture medium (Eagle's MEM supplemented wilh $5 \%$ FBS, $0.1 \%$ glucose, and 1 mm sodium pyruvate), and then placed into poly-L-lysine-coated 96-well microtiter wells or onto Aclar coverslips which were then placed in petri dishes $\left(5 \times 10^{4}\right.$ cells per microwell or coverslip). To obtain neurons, culture dishes are first treated on day 4 in vitro with $1 \mathrm{~mm}$ 5-fluoro-2-deoxyuridine (5-FDU) for $2 \mathrm{~d}$ to deplete astrocytes; the treatment was repeated three times over a 2 week time period. These neurons are used in functional assays within $14 \mathrm{~d}$.

To obtain astrocytes, nontreated fetal CNS-derived dissocated cultures cultures were passaged two or three times using $0.25 \%$ trypsin for $5 \mathrm{~min}$ at $37^{\circ} \mathrm{C}$ when cultures were confluent. Cells could be reseeded into either 96-well microwells or onto coverslips $\left(2.5 \times 10^{4}\right.$ cells per ml) $24 \mathrm{hr}$ prior to use in functional assays.

Human glioma cell lines. Cell line U251 was obtained from ATCC, and maintained in serial passage in RPMI supplemented with 5\% FCS. Cells were trypsinized and reseeded for functional assays, as described for fetal astrocytes. Additional studies were conducted using the A172 glioma cell line; results were comparable to those with the U25l cells.

\section{Immunocytochemistry}

The individual neural cell types were characterized by immunostaining. OLs were identified using the mouse anti-R monoclonal antibody (mAb), H8H9 (Ranscht et al,, 1982), derived from hybridoma supernatant, followed by goat anti-mouse IgG conjugated with Texas red (Jackson Immunoresearch Lab, West Grove, PA). Neurons were identified by staining with anti-MAP 2 mAb (1:1000 dilution), SMI52, (Sternberger-Meyer Immunocytochemicals, Whitehall, MD), followed by biotinylated horse anti-mouse $\operatorname{IgG}$ ( $1: 100$ dilution), followed by fluorescein-conjugated streptavidin (Boehringer-Manheim, Laval, Quebec). Additional antibodies used to identify neurons included anti-neurofilament SMI33 (Sternberger-Meyer), anti-neuron-specific enolase (NSE) (Dako, Westchester, PA). and anti-Tau (Sigma \#T-5530, St. Louis, MO) mAbs. Rabbit anti-glial fibrillary acidic protein (GFAP) Ab was used as the astrocyte marker. Neuron and astrocyte staining involved fixation of cells in acid alcohol (5\% glacial acetic acid, $95 \%$ absolute alcohol) for $15 \mathrm{~min}$. Except for fixation, which was done at $-20^{\circ} \mathrm{C}$, all steps were performed at room temperature. The OL-directed immunostaining was done on live cells without fixation. Cells on coverslips were incubated with all primary and secondary antibodies for 45 min; cells were washed three times in PBS between incubations. After staining, previously nonfixed cells were tixed in $2 \%$ paraformaldehyde (20 min).

\section{Assays of neural cell injury}

$\mathrm{TNF} \alpha$ or $\mathrm{CD}^{+} \mathrm{T}$ cells were added to cultures of target cells contained in 24- or 96-well microtiter plates at concentrations of effector:target (E:T) ratios and for the time durations indicated in the Results section. Initial studies established that TNF $\alpha$ effects were concentration dependent and that $\mathrm{CD}^{+} \mathrm{T}$-cell activity was dependent on E:T ratio (Antel et al., 1994). Most T-cell-mediated injury studies reported here were performed at a 10:1 E:T ratio.

Cell membrane-directed injury. These studies were conducted over either 5 or $18 \mathrm{hr}$ using ${ }^{51}$ Chromium $(\mathrm{Cr})$ release as the standard measure of cell membrane injury. For the ${ }^{51} \mathrm{Cr}$ assay, target cells were labelled overnight with $0.1 \mu \mathrm{Ci}$ of " $\mathrm{Cr}$ (NEN DuPont, Mississauga, Ontario) per well of 96-well microtiter places. Cells were then washed twice in PBS before addition of TNF $\alpha$ or CD4 $+\mathrm{T}$ cells at indicated concentrations or E:T ratios. After 5 or $18 \mathrm{hr}, 100 \mu \mathrm{l}$ of cell-free supernatant was collected from individual microwells to determine induced ${ }^{51} \mathrm{Cr}$ release (IR). One hundred microliters of $5 \mathrm{~N}$ sodium hydroxide (Fisher Scientific) was then added to each well for $30 \mathrm{~min}$, and a further $100 \mu \mathrm{l}$ was collected to determine residual ${ }^{51} \mathrm{Cr}$ release (RR). Percentage nonspecific ${ }^{\text {sI }} \mathrm{Cr}$ release (NSR) was determined from microwells containing only target cells by $(\mathrm{SR} /(\mathrm{SR}+\mathrm{RR})) \times 100$, where $\mathrm{SR}$ is spontaneous release. Percentage specific release was calculated as $[(I R /(I R+R R))$ - NSR] $\times 100$.

In some studies, an LDH release assay (as described below) was used, although in this assay the cell source (effector or target) of released LDH would be uncertain.

For the TNF $\alpha$ studies, the LDH release assay was used as the standard assay at both the 18 and $96 \mathrm{hr}$ time points. For this assay, culture supernatants werc collected and analyzed using a commercial kit (Sigma). Results are expressed as LDH units of test samples $\div$ LDH units of culture medium alone $\times 100 \%$. The assay is insufficiently sensitive to detect LDH in serum-free conditions.

Nuclear injury (apoptosis). These studies were performed over a 18 $96 \mathrm{hr}$ time period on cells contained on coverslips placed into 24-well microtiter plates. Given that our cell targets of injury are nondividing primary cells and are available only in relatively small cell numbers, we have utilized, as our measures of nuclear injury, propidium iodide (PI) staining to identify changes in nuclear morphology (fragmentation, condensation of chromatin) and the terminal transferase (TdT)-mediated dUTP-biotin nick end labeling (TUNEL) technique to identify DNA fragmentation. PI staining was carried out on acetone:methanol or acid alcohol fixed coverslips. After rehydration for $30 \mathrm{~min}$ in PBS, coverslips 
were stained with PI ( $10 \mu \mathrm{g}$ per $\mathrm{ml}, 20 \mathrm{~min}$ incubation), washed in PBS, and mounted for counting. For the TUNEL assay, coverslips containing the specific cell type were incubated for $1 \mathrm{hr}$ at $37^{\circ} \mathrm{C}$ with 50 $\mu l$ of nick end laheling solution containing TdT $(0.3 \mathrm{U} / \mathrm{ml})$ and biotinylated dUTP $(0.01 \mathrm{nmol} / \mathrm{ml})$ in TdT buffer (Promega). The reaction was terminated by transferring the coverslips into microwells containing Tris buffer for $15 \mathrm{~min}$ at room temperature. After blocking with $2 \%$ BSA for 15 min and washing, the coverslips were incubated with streptavidin-FITC $\left(1: 20,30 \mathrm{~min}\right.$ at $\left.37^{\circ} \mathrm{C}\right)$ (Boehringer-Manheim).

We have used serum deprivation, a commonly used means to induce apoptosis in many cell lines, as a means to determine whether our target cells will show evidence of nuclear injury in the above assays.

TUNEL and PI quantitative data were obtained by counting coded slides. At least 200 cells per slide were counted. The number of coverslips counted and the number of individual experiments included for each test condition are indicated in the figures. In some studies, the total number of cells present in a defined area of a coverslip was determined under control and test conditions. ${ }^{51} \mathrm{Cr}$ and LDH data are presented as means \pm SEM for the number of experiments performed; each experiment was performed in triplicate.

\section{Results}

\section{Properties of target cells}

The morphologic and/or immunocytochemical features of the neural cells used in this study are illustrated in Figure 1. Purity of the OLs in enriched cultures was estimated at $80-90 \%$ during the 2-4 week culture period. Contaminating cells included astrocytes and fibroblasts. The latter overgrew the culture over longer time periods. The fetal cortical neurons were estimated to comprise $80-90 \%$ of cells in their cultures, with $\mathrm{GFAP}^{+}$astrocytes being the other cell type. Although only immunoreactivity with MAP $2 \mathrm{mAb}$ is illustrated, these cells could be immunostained with anti-neurofilament, anti-NSE, and anti-Tau mAbs. The U251 glioma line has lost GFAP immunoreactivity.

\section{Target cell susceptibility to TNF $\alpha$-mediated injury}

Membrane-directed injury. Levels of LDH measured in supernatant of $5 \%$ serum-supplemented cultures of OLs, neurons, and astroglia did not differ between those which did or did not contain TNF $\alpha$ (Table 1).

Nucleus-directed injury. Addition of a single dose of 1000 units of TNF $\alpha$ to $5 \%$ serum-supplemented OL-enriched cultures resulted in nuclear fragmentation in a significant proportion of OLs at $96 \mathrm{hr}(66 \pm 3 \%, n=6)$ compared to control cultures ( 7 $\pm 0.6 \%, p<0.01$ ) by PI criteria (Fig. 2). A similiar proportion of OLs $(68 \pm 2 \%)$ showed DNA fragmentation as determined by TUNEL assay (Fig. 1, Table 2). This effect was not apparent at $24 \mathrm{hr}$. The proportion of OLs showing TNF $\alpha$-induced nuclear fragmentation at $96 \mathrm{hr}$ was significantly greater than that induced by serum deprivation $(43 \pm 3 \%, n=6, p<0.01$ ). The number of OLs remaining in the TNF-treated and nontreated cultures after $96 \mathrm{hr}$ did not differ significantly (Table 1 ).

The proportion of fragmented nuclei in neurons exposed to TNF for $96 \mathrm{hr}$ was significantly increased over control values $(10 \pm 1 \%$ vs $6 \pm 0.4 \%, n=7, p<0.01)$. This proportion was, however, markedly lower than that for OLs and significantly lower than that induced by serum deprivation $(25 \pm 3 \%, n=$ $7, p<0.001$ ).

The proportion of fragmented nuclei in glioma cells was not significantly increased in cultures containing $5 \%$ serum plus $1000 \mathrm{U} / \mathrm{ml}$ of TNF $\alpha(7 \pm 0.9 \%, n=6)$ compared to control values $(5 \pm 0.6 \%, n=6$ ) (Fig. 2). Serum deprivation alone augmented nuclear fragmentation only to a small extent ( $12 \pm$ $2 \%, n=3$ ). Fragmentation of nuclei could be more readily observed in these cells by combining reduced serum conditions $(1 \%)$ and $\mathrm{TNF} \alpha(35 \pm 3 \%, n=5, p<0.001)$. Similiar results were obtained with the TUNEL assay ( $42 \pm 3 \%, n=3$ ) (Table 2 ). The fetal astrocytes did not undergo significant nuclear fragmentation (Fig. 2) or DNA fragmentation in response to either TNF $\alpha$ and/or low serum conditions. The overall correlation coefficient between the results of the PI assay of nuclear fragmenlation and the TUNEL assay of DNA fragmentation in the above TNF assays and the CD4 ${ }^{+} \mathrm{T}$-cell effector assays described below was $0.979, n=14$.

\section{Target cell susceptibility to $C D 4^{+} T$-cell-mediated injury}

Membrane-directed injury. As shown in Figure 3 and Table 1, the membrane-directed lytic capacity of $\mathrm{CD}^{+} \mathrm{T}$ cell at $24 \mathrm{hr}$ was found to be dependent on the method of $\mathrm{T}$-cell activation. Pha-activated $\mathrm{CD} 4+\mathrm{T}$ cells induced significant ${ }^{5 /} \mathrm{Cr}$ release from each of the neural cell targets, with release being highest in the proliferating cell targets (fetal astrocytes and glioma cells). These results were confirmed in the LDH assay (Table 1). Significant loss of both OLs and glioma cells, the only two target cells examined, was observed following their exposure to the pha-activated $\mathrm{CD} 4{ }^{+} \mathrm{T}$ cells (Table 1). Pha-activated $\mathrm{CD} 4{ }^{+} \mathrm{T}$ cell-mediated ${ }^{51} \mathrm{Cr}$ release could be detected as early as $5 \mathrm{hr}$ in effector:target cocultures (data not shown).

$\mathrm{CD}^{+} \mathrm{T}$ cells activated with anti-CD3 and IL-2 also induced significant ${ }^{51} \mathrm{Cr}$ release from all neural cell targets tested in the $18 \mathrm{hr}$ assay, with no apparent differences amongst the targets in their relative suceptibilities (Fig. 3). Significant cell loss could not be detected for either the OLs or gliomas (Table 2). CD4 ${ }^{+}$ $\mathrm{T}$ cells activated by anti-CD3 alone did not induce significant ${ }^{51} \mathrm{Cr}$ release from neurons, astrocytes, or glioma cells (Fig. 3). A low and variable level of OL-directed cytotoxicity was found. Studies using glioma cells as targets indicated that anti-CD3activated $\mathrm{T}$ cells could induce ${ }^{51} \mathrm{Cr}$ release of previously resistant targets if the effector cells were coated with pha just prior to being added to the previously "resistant" target cells $(6 \pm 5 \%$ for uncoated vs $19 \pm 2 \%$ for pha-coated anti-CD3-activated effectors, $n-2$ ).

${ }^{3} \mathrm{H}$-thymidine uptake was comparable between $\mathrm{CD} 4^{+} \mathrm{T}$ cells activated by pha $(34226 \pm 5591 \mathrm{cpm}, n=4)$ or anti-CD3 (38355 $\mathrm{cpm} \pm 5534, n=4)$; uptake by anti-CD3 and IL-2activated cells was significantly higher $(59252 \pm 7788 \mathrm{cpm}, n$ $=4, p<0.05)$. Purity of $\mathrm{CD}^{+} \mathrm{T}$ cells did not differ as a function of activation conditions (mean percent CD4 ${ }^{+} \mathrm{T}$ cells derived from anti-CD3-activated cultures was $89 \pm 3 \%$; from anti-CD3 plus IL-2-activated cultures $87 \pm 3 \%$; and, from phaactivated cultures $92 \pm 2 \%, n=7$ ) as assessed using flow cytometry. There were less than $2 \% \mathrm{CD}^{+} \mathrm{T}$ cells or NK cells.

Total ${ }^{51} \mathrm{Cr}$ labelling of the various cell targets used did not vary widely (for OLs: 5000-7000 cpm; for neurons: 2500-3000 cpm; for astrocytes and glioma cells: $6000-8000 \mathrm{cpm}$ ). Nonspecific release was comparable among the neural cells, with a mean range of $26-33 \%$. These values are higher than those found using a $5 \mathrm{hr}$ Cr51 release assay.

Nucleus-directed injury. Although all target cells released ${ }^{51} \mathrm{Cr}$ upon coculture with pha-activated $\mathrm{CD} 4^{+} \mathrm{T}$ cells, only in the glioma cells was there a significant increase in the proportion of fragmented nuclei compared to control cultures, as measured either by PI staining or TUNEL technique (Fig. 2, Table 2). The proportion was increased as early as $18 \mathrm{hr}$, with a further increase by $96 \mathrm{hr}$.

\section{Discussion}

We have utilized dissociated cultures of human CNS-derived cells to examine the relative susceptibility of these cells to TNF- 

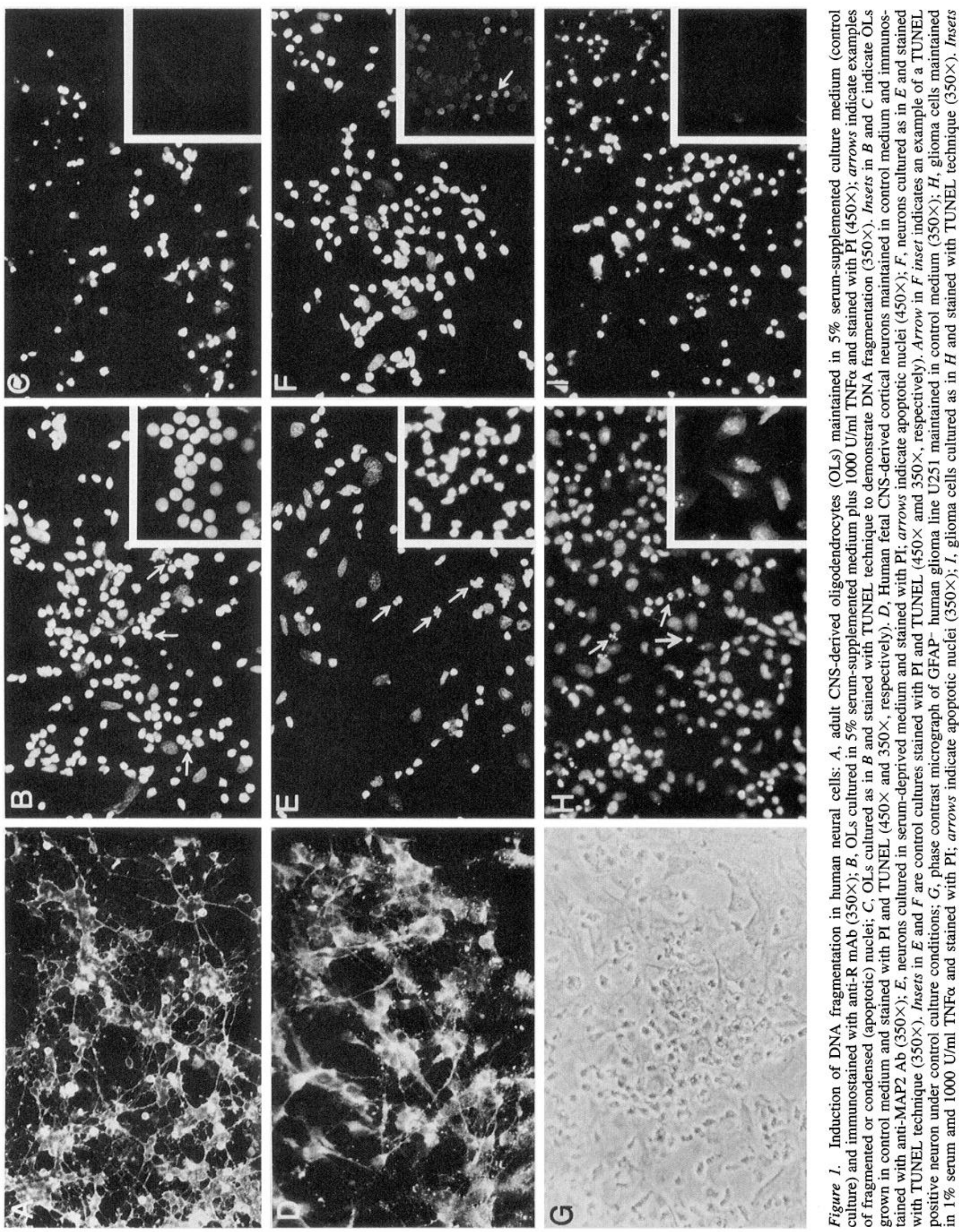

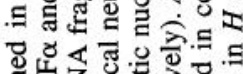
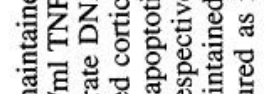

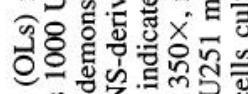
\&ै 8 乙

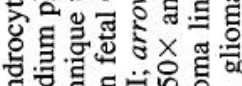

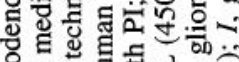

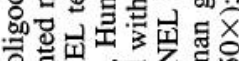

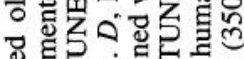

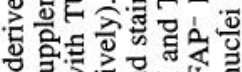

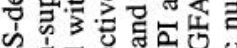

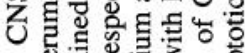

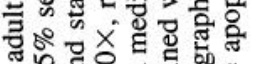
<.I ส

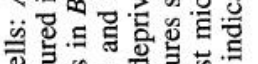

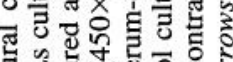

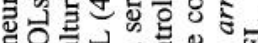

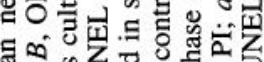

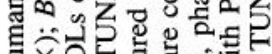
주열

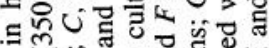

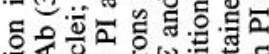

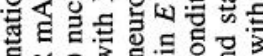

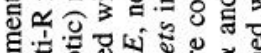
要等

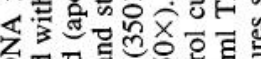

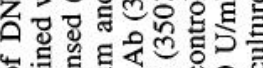
范

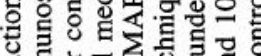

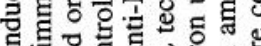

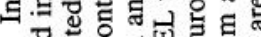

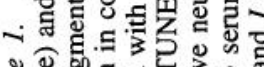
웛요

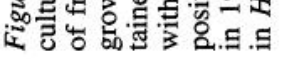


Table 1. Effects of TNF $\alpha$ and activated $\mathrm{CD4}^{+} \mathrm{T}$ cells on target cells-release of $\mathrm{LDH}$ and cell survival

\begin{tabular}{|c|c|c|c|c|c|}
\hline \multirow[b]{3}{*}{ Effector } & \multicolumn{5}{|c|}{ Target cells } \\
\hline & \multicolumn{3}{|c|}{$\begin{array}{l}\text { LDH release } \\
\text { (\% of control) }\end{array}$} & \multicolumn{2}{|c|}{$\begin{array}{l}\text { Surviving cell numbers } \\
\text { (\% of control) }\end{array}$} \\
\hline & OLs & Neurons & Glioma & OLs & Glioma \\
\hline $\mathrm{TNF} \alpha$ & $\begin{array}{l}96 \pm 1 \% \\
n=3\end{array}$ & $\begin{array}{l}121 \pm 11 \% \\
n=3\end{array}$ & $\begin{array}{l}110 \pm 6 \% \\
n=3\end{array}$ & $\begin{array}{l}102 \pm 12 \% \\
n=4\end{array}$ & ND \\
\hline $\begin{array}{l}\mathrm{CD}^{+}+\mathrm{T} \text { cells }+ \\
\text { pha }\end{array}$ & $173 \%$ & ND & $\begin{array}{l}250 \% \\
(249,250)\end{array}$ & $\begin{array}{l}40 \pm 9 \% \\
n=3\end{array}$ & $\begin{array}{l}29 \pm 4 \% \\
n=3\end{array}$ \\
\hline anti-CD3-IL2 & $185 \%$ & ND & $\begin{array}{l}206 \% \\
(186,225)\end{array}$ & $\begin{array}{l}103 \pm 30 \% \\
n=3\end{array}$ & $\begin{array}{l}97 \pm 7 \% \\
n=3\end{array}$ \\
\hline anti-CD3 & $\begin{array}{l}126 \% \\
n=2\end{array}$ & ND & $\begin{array}{l}126 \% \\
(135,117)\end{array}$ & $\begin{array}{l}92 \pm 19 \% \\
n=3\end{array}$ & $\begin{array}{l}91 \pm 2 \% \\
n=3\end{array}$ \\
\hline
\end{tabular}

Comparison of $\mathrm{LDH}$ release and number of surviving target cells in effector:target cocultures with that found in cultures containing target cells alone. For LDH studies, data are expressed as LDH in test cultures $\div$ LDH in control cultures $\times 100 \%$ for the number of experiments performed \pm SEM, except when unly single experiments (single value shown) or duplicate experiments (averaged and individual results shown) were performed. For single and duplicate experiments, each data point represents mean of triplicate cultures. Culture medium alone contains $400-$ $600 \mathrm{U}$ of LDH. LDH values of cultures containing target cells only did not differ significantly from medium alone values. For cell survival studies, data are expressed as number of target cells in a defined coverslip region of an effector:target cocuiture $\div$ number of cells in a defined coverslip region of a target-cell-only culture $\times 100 \% \pm$ SEM for the number of experiments performed. ND, Not done
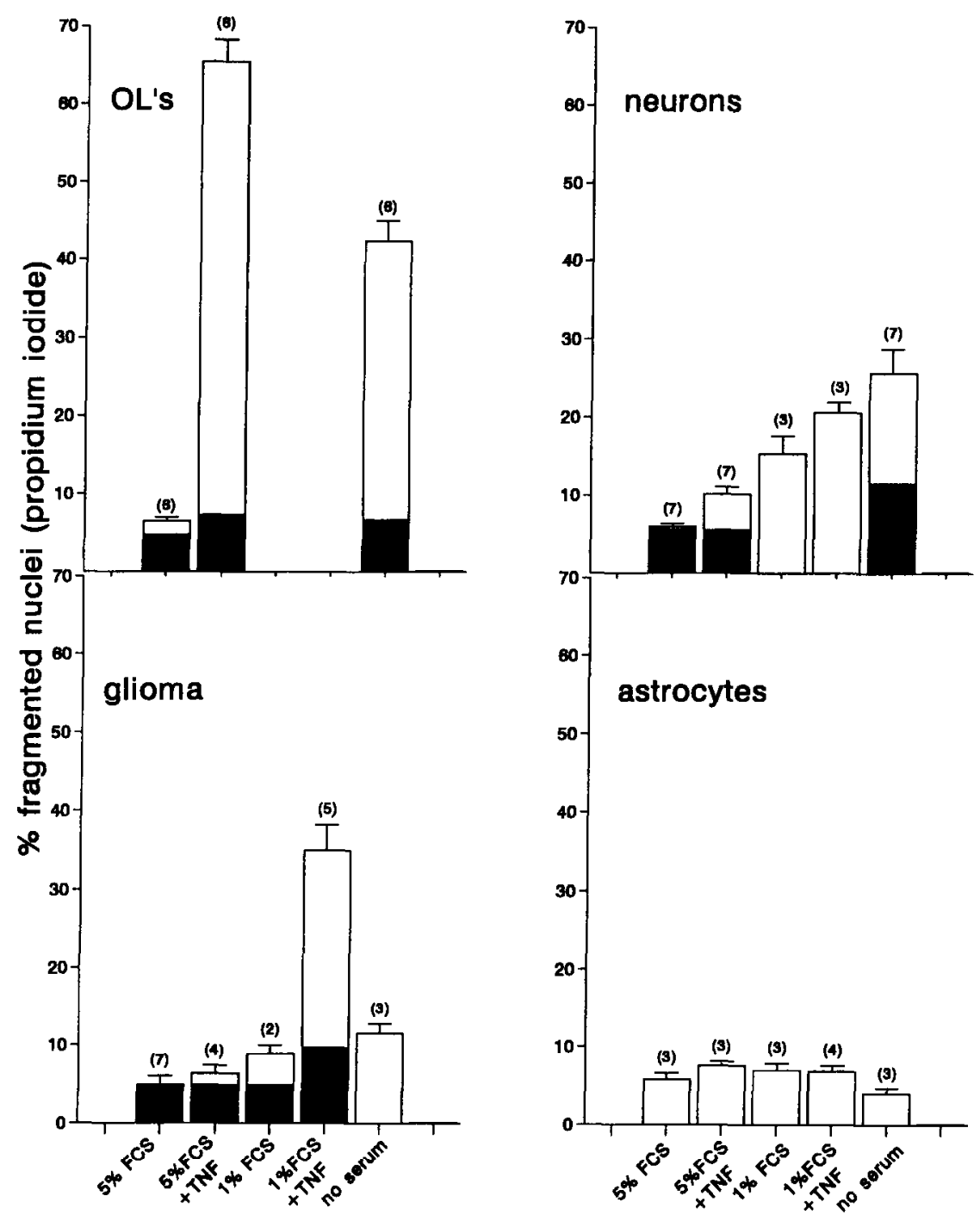

Figure 2. Susceptibility of human neural cells to TNF $\alpha$-induced nuclear injury, propidium iodide (PI) assay; bars indicate percentage \pm SEM of OLs, neurons, glioma, and fetal astrocytes which show morphologic features of nuclear fragmentation after $96 \mathrm{hr}$ in tissue culture medium containing either 5\% FCS, 5\% FCS plus $1000 \mathrm{U} / \mathrm{ml}$ TNFo, 1\% FCS, $1 \%$ FCS plus TNFa, or no serum. Solid portions of bars indicate percentage of cells with fragmented nuclei found at $18 \mathrm{hr}$. For each test condition the number of coverslips counted is indicated. At least two invdividual experiments were performed for each condition. 
Table 2. Extent of DNA fragmentation (TUNEL assay) of target cells in response to effector conditions inducing significant nuclear fragmentation (PI assay)

\begin{tabular}{|c|c|c|c|}
\hline Target cell & Effector condition & $\begin{array}{l}\text { TUNEL } \\
\text { (\% positive cells) }\end{array}$ & $\begin{array}{l}\text { PI } \\
\text { (\% fragmented } \\
\text { nuclei) }\end{array}$ \\
\hline \multirow[t]{2}{*}{ OLs } & TNF $\alpha$ & $68 \pm 2 \%(6)$ & $66 \pm 3 \%(6)$ \\
\hline & Senum deprivation & ND & $43 \pm 3 \%(6)$ \\
\hline Neurons & Serum deprivation & $32 \pm 2 \%(2)$ & $25 \pm 3 \%(7)$ \\
\hline \multirow[t]{2}{*}{ Glioma } & $\mathrm{TNF} \alpha+1 \%$ serum & $42 \pm 3 \%(3)$ & $35 \pm 3 \%(5)$ \\
\hline & pha-activated $\mathrm{CD} 4^{+} \mathrm{T}$ cells & 33 & $22 \pm 1 \%(4)$ \\
\hline
\end{tabular}

Data indicate results of PI and TUNEL assays obtained for the same test conditions, in which significantly elevated values for the proportion of cells with nuclear injury were found. Data are expressed as mean \pm SEM\% for the number of coverslips counted. At least two experiments were done for each condition, except glioma plus phaactivated $T$ cells where a single coverslip was counted.

and non-TNF-dependent effector mechanisms, the latter mediated by activated $\mathrm{CD} 4^{+} \mathrm{T}$ cells acting in a non-MHC-restricted manner. The target response was assessed in terms of the two major categories of cell injury, namely primary cell membranedirected injury (lysis) and nucleus-directed injury (apoptosis) (Zychlinsky et al., 1991; Taylor and Cohen, 1992; Cohen, 1993; Louis et al., 1993; Schwartzman and Codlowski, 1993), and in terms of the time required for the response to develop. The results indicated that the target cells studied (OLs, neurons, and malignant and nonmalignant astrocytes) differed in their relative susceptibilities to these effector mechanisms and in the nature of the cellular injury which occurred.

The susceptibility of human adult CNS-derived OLs to the nuclear injury-inducing effects of TNF $\alpha$ that we found in our
Figure 3. Susceptibility of human neural cells to cell membrane injury as measured by ${ }^{51} \mathrm{Cr}$ release and to nuclear fragmentation as measured by PI staining, induced by $\mathrm{CD}^{+} \mathrm{T}$ cells activated by either PHA antibody (hatched bars), anti-CD3 plus IL-2 (open bars), or anti-CD3 antibody (solid bars). Studies were performed at 10:1 E:T ratios. $U p$ per panel indicates mean percentage specific ${ }^{51} \mathrm{Cr}$ release \pm SEM at $18 \mathrm{hr}$ for the number of individual studies indicated for each target cell type. Lower panel indicates mean percentage \pm SEM of fragmented muclei for the corresponding target cells, as determined at $96 \mathrm{hr} ; 18 \mathrm{hr}$ data is indicated by arrows. Number of coverslips or experiments used in each condition is indicated.

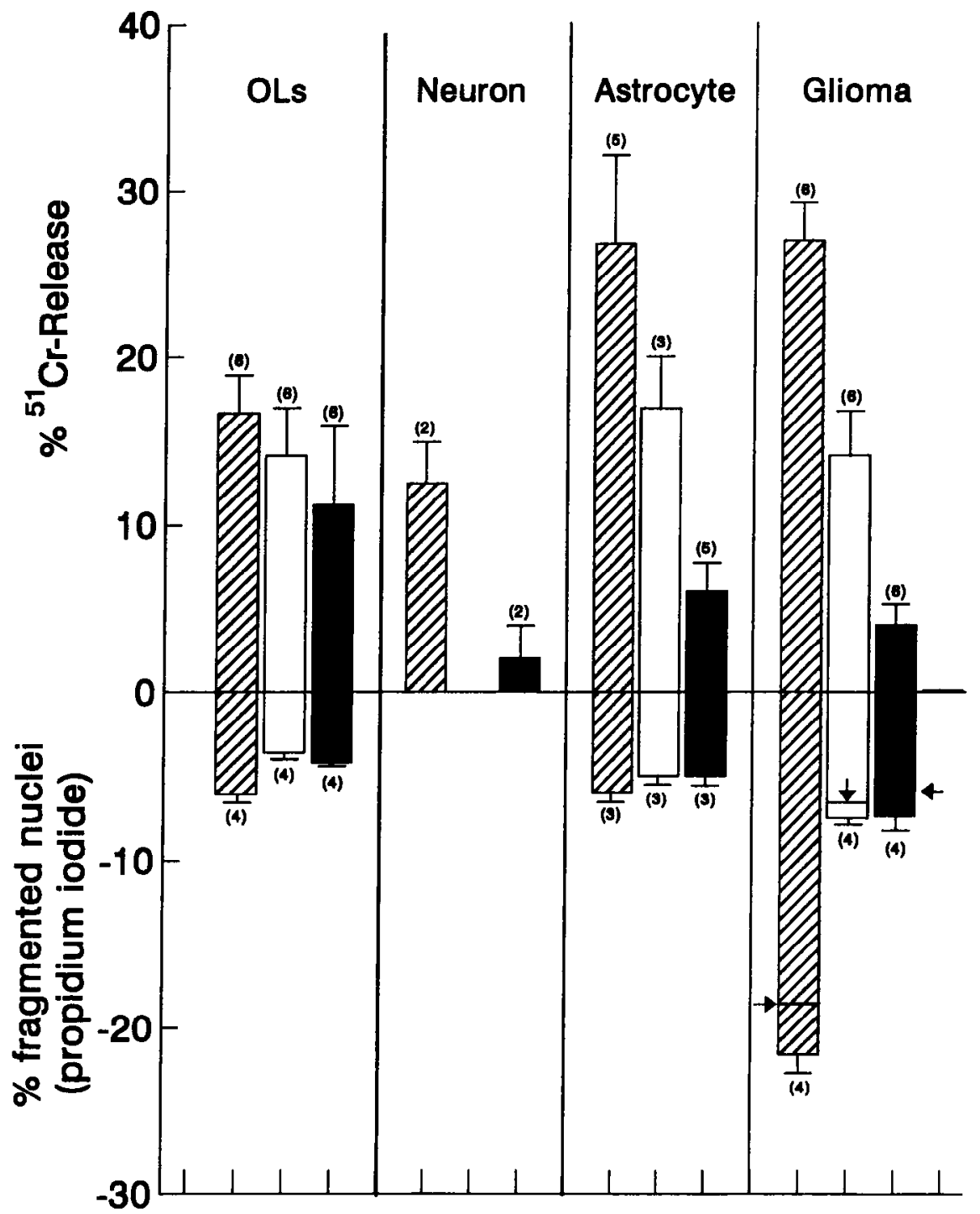


study are consistent with those observed by others using rodent and bovine primary OL cultures and a rodent OL-precursor cell line (Selmaj et al., 1991; Louis et al., 1993). Over the same time period, we did not detect significant cell membrane rupture, as assessed using ${ }^{51} \mathrm{Cr}$ or $\mathrm{LDH}$ release, nor loss of cell numbers. The latter results are consistent with those of Zajicek et al. (1992), who found that soluble human recombinant TNF $\alpha$ did not induce cytotoxicity of rodent OLs, whercas ccll-bound TNF was the putative mediator of microglia-induced cytotoxicity of $\mathrm{OI} s$ in vitro. In contrast to the OLs, the neurons, in our study, were relatively resistant to TNF $\alpha$ in terms of nuclear injury. The extent of TNF $\alpha$-induced nuclear injury of OLs was greater than that induced by serum deprivation; the reverse was observed for the human fetal neurons. Giulian et al. (1993) previously observed the greater susceptibility of neurons, compared to OLs, to noncytokine low molecular weight factors released by microglia.

Neither the malignant nor nonmalignant fetal astrocytes showed significant nuclear injury in response to TNF $\alpha$ under our usual culture conditions. In addition, we did not observe significant nuclear or DNA fragmentation in the small proportion of astrocytes contained in our adult CNS-derived OL-enriched cultures. These results indicate the differences in susceptibility to a common effector between glial cells of apparently shared developmental lineage (Barres et al., 1992). The glioma cells, but not the nonmalignant astrocytes, showed significant nuclear and DNA fragmentation in response to the combination of serum deprivation and TNF $\alpha$. The glioma cells had a higher rate of proliferation than did the fetal astrocytes; the proliferation of the latter was higher than that of the adult CNS-derived astrocytes (Yong et al., 1992). The adult astrocytes can be shown to incorporate significant levels of BrdU in vitro in contrast to the OLs (Grenier et al., 1989).

Nuclear injury was assessed using morphologic criteria of PIstained cells and a fluorescence DNA fragmentation assay (TUNEL). A strong correlation was found between results in the two assays. The numbers of OLs and neurons available and difficulties in recovering these cells from cultures limited the use of other techniques to assess DNA fragmentation, such as DNA ladders or FACS analysis. The former would have limited use in the coculture systems discussed below, containing both effector and target cells.

Target cell injury mediated by $\mathrm{CD} 4^{+} \mathrm{T}$ cells depended both on the means of $\mathrm{T}$-cell activation and the cell type serving as the target. Pha-activated CD $4^{+}$T-cell lysis could be detected in $5 \mathrm{hr}$ as well as $18 \mathrm{hr}$ cocultures, suggesting that these cells had residual surface lectin, and their effect was akin to lectin-dependent cell cytotoxicity (Bevan and Cohen, 1975; Ruijs et al., 1990). Our previous studies indicated that the effect was not mediated via TNF-dependent mechanisms, in that it could not be blocked with neutralizing anti-TNF antibody or reproduced with TNF (Antel et al., 1994). CD4 ${ }^{+}$T cells have previously been demonstated to be capable of mediating both TNF-dependent and -independent cytotoxicity (Ju et al., 1990; Liu et al., 1992; Smyth et al., 1992).

$\mathrm{CD} 4^{+} \mathrm{T}$ cells activated by anti-CD3 and IL-2 induce membrane injury to a greater extent in the $18 \mathrm{hr}$ than in the $5 \mathrm{hr}$ cytotoxicity assays (Ruijs et al., 1990). The cytotoxic effect of anti-CD3 plus IL-2-activated CD4 ${ }^{+} \mathrm{T}$ cells would seem akin to that initially termed promiscuous killing in assay systems using either antigen or anti-CD3 and IL-2 to generate T-cell lines as effectors and dividing non-neural NK cell-resistant tumor lines as targets (Patel et al., 1987; Thiele and Lipsky, 1989). The $\mathrm{CD}^{+} \mathrm{T}$ cells activated by anti-CD3 alone did possess cytotoxic potential, as revealed by coating these cells with pha immediately prior to adding them to target cells. IL-2 augmented cytotoxicity mediated by anti-CD3-activated T cells has previously been described (Stohl et al., 1990; Nishimura et al., 1992). The lack of cytotoxicity found using $\mathrm{CD}^{+}{ }^{+} \mathrm{T}$ cells activated with anti-CD3 alone, compared to anti-CD3 plus IL-2, suggests that residual anti-CD3 antibody on the $T$ cells is not serving as a ligand. The essential ligands involved in promiscuous T-cell killing of particular cell targets remains to be defined.

Extent of T-cell proliferation as a function of method of T-cell activation did not correlate with cytotoxicity, in that ${ }^{3} \mathrm{H}$-thymidine uptake was similar between anti-CD3- and pha-activated T cells. $T$ cells activated with anti-CD3 and IL-2 showed the highest proliferation rates. However, even at a $20: 1 \mathrm{E}: \mathrm{T}$ ratio, $\mathrm{CD}^{+}{ }^{+}$ $T$ cells activated by anti-CD3 alone did not induce the extent of ${ }^{51} \mathrm{Cr}$ release found using anti-CD3 plus IL-2-activated $\mathrm{CD} 4{ }^{+} \mathrm{T}$ cells at a lower $E: T$ ratio (data not shown), suggesting that differences in effector cell numbers that may have occurred during the co-culture period did not account for the functional results. Any remaining exogenous IL-2 in the anti-CD3 plus IL-2-activated cultures would have been removed at the time the $T$ cells were washed prior to adding them to the cell targets. The T-cell populations used were highly enriched for $\mathrm{CD}^{+} \mathrm{T}$ cells, and thus the effects induced are unlikely to be due to a small population of NK cells (Galandrini et al., 1994). Mechanisms of $\mathrm{CD}^{+} \alpha / \beta$ T-cell receptor (TcR) bearing T-cell-mediated cytotoxicity may differ from those used by other $\mathrm{T}$-cell populations, including $\mathrm{CD} 8^{+} \mathrm{T}$ cells and $\gamma / \delta$ TcR-bearing $\mathrm{T}$ cells (Smyth, 1992).

With regard to the target cell response to pha-activated $T$ cells, only in the glioma cells did DNA and nuclear fragmentation develop. Significant fragmentation was observed within $18 \mathrm{hr}$, a time period which precedes that required for TNF $\alpha$ and serum depletion-induced fragmentation to occur. Cell numbers were reduced in all cell cultures exposed to pha-treated CD4 ${ }^{+} \mathrm{T}$ cells. The lack of DNA and nuclear fragmentation in the nonglioma neural cells would seem to differ from previous studies of $\mathrm{CD} 4^{+}$ $T$-cell-mediated cytotoxicity using non-neural cell targets, in that the latter suggested that nuclear injury preceded cell disintegration (reviewed in Thiele and Lipsky, 1989; Duke, 1992; Grogg et al., 1992; Berke, 1994; Stalder et al., 1994). The glioma cells are the most actively proliferating of the cell targets used in our study. Our data suggests that primary non-dividing CNS cells, OLs, and neurons, are resistant to this pathway, although they are capable of undergoing apoptosis as shown using either TNF or serum deprivation. These data would be consistent with the existence of multiple different pathways whereby nuclear injury programs are activated (Rose and Henneberry, 1993; Schwartz et al., 1993; Schwartzman and Cidlowski, 1993; Oltavi and Korsmeyer, 1994).

Cell membrane injury mediated by the anti-CD3-activated $\mathrm{CD}^{+} \mathrm{T}$ cells was not accompanied by either the extent of DNA fragmentation (in the case of gliomas) or cell loss (found with all cell targets tested) observed using the pha-activated $T$ cells. These findings could provide a model whereby $T$ cells could induce membrane injury without necessarily cell body loss, that is, sublethal injury with potential for recovery, as suggested for complement-mediated injury (Scolding et al., 1989). Our previous studies did indicate that human OLs are susceptible to promiscuous cell-mediated cytotoxicity mediated by-MBP re- 
active CD4 ${ }^{+}$T-cell lines (Antel et al., 1994). In the case of multiple sclerosis, the issue of myelin loss, with or without OL cell loss, continues to be studied (Bruck et al., 1994).

In summary, our current in vitro data indicate the differing susceptibility and cellular response of human CNS neural cells to TNF-dependent and independent immune effector mechanisms. Therapeutic strategies applied to diseases or injury of the human CNS will need to consider this heterogeneity.

\section{References}

Antel JP, Williams K, Blain M, McCrea E, McLaurin J (1994) Oligodendrocyte lysis by $\mathrm{CD}^{+} \mathrm{T}$ cells independent of tumor necrosis factor. Ann Neurol 35:341-348.

Arnold DL, Riess GT, Matthews PM, Francis G, Collins DL, Wolfson C, Antel JP (1994) Useof proton magnetic resonance spectroscopy for monitoring disease progression in multiple sclerosis. Ann Neurol 36:76-82.

Barres BA, Hart IK, Coles HSR, Burne JF, Voyvodic JT, Richardson WD, Raff MC (1992) Cell death and control of cell survival in the oligodendrocyte lineage. Cell 70:31-346.

Berke G (1994) The binding and lysis of target cells by cytotoxic lymphocytes: molecular and cellular aspects. Annu Rev Immunol 12: 735-773.

Bevan MH, Cohen M (1975) Cytotoxic effects of antigen- and mitogen-induced $\mathrm{T}$ cells on various targets. J Immunol 114:59-565.

Bruck W, Schmied M, Suchanek G, Cruck Y, Breitschopf H, Poser S, Piddlesen S, Lassmann H (1994) Oligodendrocytes in the early course of multiple sclerosis. Ann Neurol 35:65-73.

Cohen JJ (1993) Apoptosis. Immunol Today 14:126-130.

Duke RC (1992) Apoptosis in cytotoxic T lymphocytes and their targets. Semin Immunol 4:497-512.

Galandrini R, De Maria R, Piccoli M, Frati L, Santoni A (1994) CD4 ${ }^{+}$ triggering enhances human NK cell cytotoxic functions. J Immunol 153:4399-4407.

Gelbard HA, Dzenko KA, DiLoreto D, Delcerro C, Delcerro M, Epstein LG (1993) Neurotoxic effects of TNF $\alpha$ in primary human neuronal cultures are mediated by activation of the glutamate AMPA receptor subtype-implications for AIDS neuropathogenesis. Dev Neurosci $15: 417-442$

Giulian D, Vaca K, Corpuz M (1993) Brain glia release factors with opposing actions upon neuronal survival. J Neurosci 13:229-237.

Grenier Y, Ruijs TCG, Robitaille Y, Olivier A, Antel JP (1989) DNA synthesis by young adult human-derived astrocytes in vitro. Brain Res 480:87-91.

Grogg D, Habn S, Erb P (1992) CD4 ${ }^{+}$T cell-mediated killing of major histocompatibility complex class II-positive antigen-presenting cells (APC). III. CD4 ${ }^{+}$cytotoxic T cells induce apoptosis of APC. Eur J Immunol 22:267-272.

Ju S-T, Ruddle NH, Strack P, Dorf ME, DeKruyff RH (1990) Expression of two distinct cytolytic mechanisms among murine CD4 subsets. J Immunol 144:23-31.

Lee SC, Liu W, Dickson DW, Bronsnan CF, Berman JW (1993) Cytokine production by human fetal microglia and astrocytes. Differential induction by lipopolysaccharide and IL-1 beta. J Immunol 150: 2659-2667.

Louis JC, Magal E, Takayama S, Varon S (1993) CNTF protection of oligodendrocytes against natural and tumor necrosis factor-induced death. Science 259:689-692.

McGeer PL, Akiyama H, Itagaki S, McGreer EG (1989) Immune system response in Alzheimer's disease. Can J Neurol Sci 16:516-527.

McLaurin J, D'Souza S, Stewart J, Blain M, Beaudet A, Nalbantoglu J, Antel JP (1995) Effect of tumor necrosis factor $\alpha$ and $\beta$ on human oligodendrocytes and neurons in culture. Int J Dev Neurosci 13:369381

Nishimura T, Nakamura Y, Takeuchi Y, Tokuda Y, Iwasawa M, Kawasaki A, Okumura I, Habu S (1992) Generation, propagation, and targeting of human $\mathrm{CD} 4^{+}$helper/killer $\mathrm{T}$ cells induced by anti-CD3 monoclonal antibody plus recombinant IL-2. J Immunol 148:285291
Otavi AN, Korsmeyer SJ (1994) Checkpoints of dueling dimers foil death wishes. Cell 79:189-192.

Patel SS. Thiele DL, Lipsky PE (1987) Major histocompatibility complex - unrestricted cytolytic activity of human T cells. Analysis of precursor frequency and effector phenotype. J Immunol 139:38863895

Prabakhar S, D'Souza SD, Antel JP, McI aurin I, Schipper HM, Wang E (1995) Phenotypic and cell cycle properties of adult human oligodendrocytes in vitro. Brain Res 672:159-169.

Ranscht B, Clapshaw PA, Price J, Noble M, Seifert W (1982) Development of oligodendrocytes and Schwann cells studied with a monoclonal antibody against galactocerebroside. Proc Natl Acad Sci USA 79:2709-2713.

Robbins DS, Shirazi Y, Drysdale B-E, Lieberman A, Shin HS, Shin MS (1987) Production of cytotoxic factor for oligodendrocytes by stimulated astrocytes. J Immunol 139:2593-2597.

Rose CD, Henneberry RC (1993) Mechanisms of programmed cell death and their implications for the brain. Neurodegeneration 2:287298.

Ruijs TCG, Freedman MS, Grenier YG, Olivier A, Antel JP (1990) Human oligodendrocytes are susceptible to cytolysis by major histocompatibility complex class I-restricted lymphocytes. J Neuroimmunol 27:88-97.

Schwartz LM, SMith SW, Jones MEE, Osborne BA (1993) Do all programmed cell deaths occur via apoptosis? Proc Natl Acad Sci USA 90:980-984.

Schwartzman RA, Cidlowski JA (1993) Apoptosis: the biochemistry and molecular biology of programmed cell death. Endocrine Rev 14 : 133-151.

Scolding NJ, Morgan BP, Houston WAJ, Linington C, Campbell AK, Compston DAS (1989) Vesicular removal by oligodendrocytes of membrane attack complexes formed by activated complement. Nature 339:620-622.

Selmaj K, Raine CS, Farooq M, Norton WT, Brosnan CF (1991) Cytokine cytotoxicity against oligodendrocytes. Apoptosis induced by lymphotoxin. J Immunol 147:1522-1529.

Smyth MJ (1992) Generation and cytotoxic profile of human peripheral blood CD4 ${ }^{+} \mathrm{T}$ lymphocytes. Immunol Cell Biol 70:379-380.

Smyth MJ, Norishia Y, Ortaldo JR (1992) Multiple cytolytic mechanisms displayed by activated human peripheral blood $\mathrm{T}$ cell subsets J Immunol 148:55-62.

Stalder T, Hahn S, Erb P (1994) Fas antigen is the major target molecule for $\mathrm{CD}^{+}{ }^{+} \mathrm{T}$ cell-mediated cytotoxicity. J Immunol 152:11271133.

Stohl W, Tovar Z, Talal N (1990) Generation of cytolytic activity with anti-CD3 monoclonal antibodies involves both IL-2-independent and - dependent components. J Immunol 144:3718-3725.

Taylor MK, Cohen JJ (1992) Cell-mediated cytotoxicity. Curr Opin Immunol 4:338-343

Thiele DL, Lipsky PE (1989) The role of cell surface recognition structures in the initiation of MHC-unrestricted "promiscuous" killing by $T$ cells. Immunol Today 10:375-381.

Williams K, Dooley N, Ulvestad E, Blain M, Yong VW, Antel JP (1994) Antigen presentation by astrocytes: correction of the inability of astrocytes to initiate immune responses by the addtion of microglia or the microglia-derived cytokine IL-1. J Neurosci Res 38:433-443.

Wilt SG, Milward E, Zhou JM, Nagasato K, Patton H, Rusten R, Griffith D, O'Connor M, Dubois-Dalcq M (1995) In vitro evidence for a dual role of tumor necrosis factor- $\alpha$ in human immunodeficiency virus type I encephalopathy. Ann Neurol 37:381-394.

Yong VW, Antel JP (1992) Culture of glial cells from human brain biopsies. In: Protocols for neural cell culture (Fedoroff S, Richardson A, eds), pp 81-96. New York: Humana.

Yong VW, Tejada-Berges T, Goodyer C, Antel JP, Yong FP (1992) Differential proliferative response of human and mouse astrocytes to gamma-interferon. Glia 6:269-280.

Zajicek JP, Wing M, Scolding NJ, Compston DAS (1992) Interactions between oligodendrocytes and microglia. A major role for complement and tumor necrosis factor in oligodendrocyte adherence and killing. Brain 115:1611-1631.

Zychlinsky A, Zhen LM, Liu C-C, Yong JD-E (1991) Cytolytic lymphocytes induce both apoptosis and necrosis in target cells. J Immunol 146:393-400. 